\title{
Falling Profits, Rising Profit Margins, and the Full-Employment Profit Rate
}

SINCE EARLY 1973 the major price aggregates have risen far more than can be explained by the direct effects of rising unit labor costs and higher prices for fossil fuels and other imported commodities. The margin of prices over standard unit labor costs for private nonfarm domestic output widened not only during the last phases of expansion in 1972-73 but even more sharply in the recession that followed. At today's price-cost relationships, full-employment levels of output and associated levels of productivity would generate very large profits. The full-employment profit rate (first cousin to the full-employment surplus) has risen very rapidly during the past two years, accounting for an important part of the inflation and perhaps-like its budgetary cousin-for an important part of the recession.

The behavior of two major price indexes - the deflators for private nonfarm domestic output and for the gross product of private nonfinancial corporations-was compared to various measures of unit labor costs. But first, each price index was adjusted to exclude the effect of the relative increase in domestic fossil-fuel prices since the onset of the embargo in October 1973. ${ }^{1}$ After the adjustment, each deflator excluded, at least concep-

Note: I am grateful to James Becker and Leonard Herk for research assistance, and to members of the Brookings panel for comments that improved the quality, even if they added to the length, of this sector report.

1. George Perry has calculated the dollar revenues of domestic oil producers quarterly since 1973:2; see Edward R. Fried and Charles L. Schultze, eds., Higher Oil Prices and the World Economy: The Adjustment Problem (Brookings Institution, 1975), chap. 2, 
tually, the direct effect of increases in (1) import prices; (2) farm prices; and (3) domestic fossil-fuel prices. In addition the deflator for the output of private nonfinancial corporations excludes the prices of sectors whose output is particularly hard to measure, such as households, financial institutions, and most of the residential-rental sector, with its low labor intensity.

\section{Prices in Relation to Standard Costs}

Table 1 shows the ratio of the adjusted price deflator to estimated standard unit labor costs (SULC) for each of the two sectors. The standard unit labor costs were derived, in a more or less simple-minded way, by fitting productivity in each sector (quarterly) to a time trend plus a cyclical term, the ratio of actual to potential gross national product in each quarter. In the private nonfarm sector two time trends are incorporated, one for 1954-64 and one for 1965-75, but the cyclical adjustment is constrained to be the same in both periods. ${ }^{2}$ This formulation is clearly misspecified with respect to very short-run movements, since actual productivity always falls below trend in the early stages of a recession by more than the equation predicts. But for movements of more than a few quarters the equation captures the cyclical swings (see the appendix). Standard unit labor costs are then derived by setting the ratio of actual to potential GNP at 0.97 , and allowing only the trend movement in productivity to affect unit labor costs; an index of the ratio of prices to standard costs, so defined, for the private nonfarm sector, is depicted in figure 1.

As table 1 shows, prices in both sectors fell gradually relative to standard unit labor costs during the period preceding the introduction of wage and

table 2-4. A calculation was made of the excess of the increase in these revenues, compared with what would have occurred had oil prices risen at the same rate as the private nonfarm deflator. An estimated increment, gradually increasing over time, was added to take account of rising prices for coal and natural gas; the increment equaled 30 percent by early 1975 . The resulting dollar value of increased revenues accruing to producers of domestic fossil fuel was divided by the current-dollar value of the private nonfarm GNP to yield the price adjustment. A correction was made to eliminate estimated revenues of noncorporate fossil-fuel producers, and a similar calculation was carried out for the private nonfinancial corporate sector. By early 1975 the adjustment lowered the private nonfarm deflator by 1.5 percent and the deflator for the private nonfinancial corporate sector by 1.8 percent.

2. The data for private nonfinancial corporations are fitted from 1958 on, since the data are available only since then. 


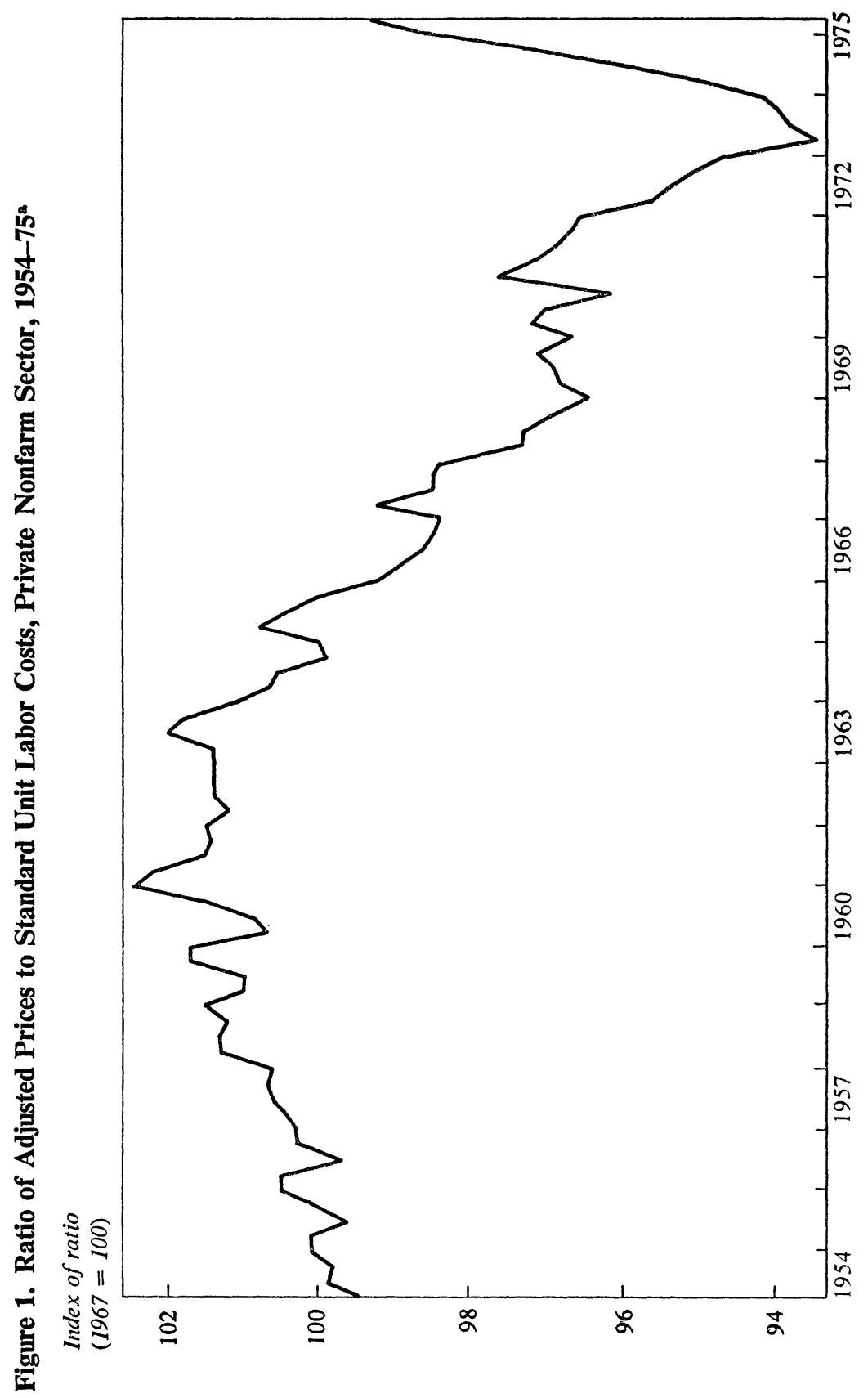


Table 1. Ratio of Adjusted Prices to Standard Unit Labor Costs, Private Nonfarm and Nonfinancial Corporate Sectors, 1965-75 a

\begin{tabular}{|c|c|c|}
\hline \multirow[b]{2}{*}{$\begin{array}{c}\text { Year } \\
\text { and } \\
\text { quarter }\end{array}$} & \multicolumn{2}{|c|}{ Sector } \\
\hline & $\begin{array}{c}\text { Private } \\
\text { nonfarm }\end{array}$ & $\begin{array}{c}\text { Private } \\
\text { nonfinancial } \\
\text { corporate }\end{array}$ \\
\hline 1965 & 100.1 & 99.9 \\
\hline 1966 & 98.6 & 99.2 \\
\hline 1967 & 98.7 & 99.9 \\
\hline 1968 & 97.0 & 98.4 \\
\hline 1969 & 96.8 & 97.2 \\
\hline 1970 & 97.0 & 97.6 \\
\hline 1971:1 & 97.1 & 97.4 \\
\hline 2 & 96.8 & 97.3 \\
\hline 3 & 96.6 & 97.0 \\
\hline 4 & 96.5 & 96.9 \\
\hline 1972:1 & 95.6 & 96.0 \\
\hline 2 & 95.3 & 96.0 \\
\hline 3 & 95.0 & 96.0 \\
\hline 4 & 94.6 & 95.9 \\
\hline 1973:1 & 93.4 & 94.5 \\
\hline 2 & 93.8 & 94.8 \\
\hline 3 & 94.0 & 95.1 \\
\hline 4 & 94.2 & 95.0 \\
\hline 1974:1 & 95.0 & 95.8 \\
\hline 2 & 96.1 & 96.6 \\
\hline 3 & 97.3 & 97.7 \\
\hline 4 & 98.6 & 98.6 \\
\hline $1975: 1$ & 99.3 & 98.6 \\
\hline 2 & 99.0 & ... \\
\hline
\end{tabular}

Sources: Underlying data on prices, compensation per manhour, and productivity from U.S. Bureau of Labor Statistics, Chartbook on Prices, Wages, and Productivity, various issues. Standard unit labor costs were derived as explained in the text. Also see the text for a description of the adjustment to the price indexes.

a. The ratios are derived from underlying indexes for which $1967=100$.

price controls in August 1971. Margins were then squeezed more tightly until early 1973, when Phase III was introduced. In the two subsequent years, however, the margin of prices over standard unit labor costs recovered not only the losses imposed by price controls but all of those suffered in the seven years since the mid-1960s. A substantial part of the price rise from 1973:1 to $1975: 1$ is attributable to the increase in this margin: ${ }^{3}$

3. The change attributable to the gross increase in the margin is the difference between the actual price change and the price change with a constant percentage markup over standard unit labor costs. 


$\begin{array}{cc}\text { Private } & \begin{array}{c}\text { Private } \\ \text { nonfinancial }\end{array} \\ \text { nonfarm } & \text { corporate } \\ \text { sector } & \text { sector }\end{array}$

Increase in percentage markup over standard unit labor costs

Most price equations that relate prices to standard unit labor costs also assign a modest pricing effect to deviations of actual from standard costs. To what extent could the rise in the ratio of price to standard unit labor costs be due to this effect? For each of the two sectors the following equation was fitted for quarterly percent changes in prices:

$$
\text { (1) } P_{t}=a_{0}+\sum_{i=t}^{t-3} a_{1 i} S U L C_{i}+\sum_{i=t}^{t-1} a_{2 i}\left(A U L C_{i}-S U L C_{i}\right)+u_{t},
$$

where

$$
\begin{aligned}
P_{t} & =\text { price deflator } \\
S U L C & =\text { standard unit labor costs } \\
A U L C & =\text { actual unit labor costs } \\
u & =\text { error term. }
\end{aligned}
$$

All variables are expressed as quarterly changes in logarithms; the private nonfarm sector was fitted from 1954:1 to $1971: 3$, and the private nonfinancial corporate sector from 1958:1 to 1971:3.

The results are shown in table 2. The purpose of this particular equation was not to determine either the best structural or the most useful predictive relationship but to capture the historical behavior of prices relative to unit labor costs. The data were fitted only through the third quarter of 1971 to avoid incorporating the effect either of price controls or of the increase in the gross margin since their removal.

In table 3 , the movement of prices since the quarter immediately preceding price controls $(1971: 2)$ is compared to an extrapolation based on the equations on unit labor cost. (The actual prices have again been adjusted to remove the effect of increases in the relative price of domestic fossil fuels.) 
Table 2. Estimates of Equation (1), Private Nonfarm and Nonfinancial Corporate Sectors ${ }^{\mathrm{a}}$

\begin{tabular}{|c|c|c|c|c|c|c|}
\hline \multirow{3}{*}{$\begin{array}{l}\text { Variable } \mathrm{b} \text { and } \\
\text { summary statistic }\end{array}$} & \multirow{3}{*}{\multicolumn{2}{|c|}{ Parameter }} & \multicolumn{4}{|c|}{ Sector } \\
\hline & & & \multicolumn{2}{|c|}{$\begin{array}{l}\text { Private } \\
\text { nonfarm }\end{array}$} & \multicolumn{2}{|c|}{$\begin{array}{c}\text { Private } \\
\text { nonfinancial } \\
\text { corporate }\end{array}$} \\
\hline & & & Coefficient & t-statistic & Coefficient & $t$-statistic \\
\hline \multicolumn{7}{|l|}{ Variable } \\
\hline Constant & $a_{0}$ & & 0.126 & $\ldots$ & 0.074 & $\cdots$ \\
\hline$S U L C$ & $a_{1}$ & $\begin{array}{l}(t) \\
(t-1) \\
(t-2) \\
(t-3) \\
\Sigma a_{1 i}\end{array}$ & $\begin{array}{l}0.231 \\
0.202 \\
0.173 \\
0.145 \\
0.751\end{array}$ & $\begin{array}{r}4.6 \\
8.5 \\
6.8 \\
2.7 \\
10.1\end{array}$ & $\begin{array}{l}0.312 \\
0.231 \\
0.150 \\
0.069 \\
0.762\end{array}$ & $\begin{array}{l}5.2 \\
8.4 \\
5.1 \\
1.1 \\
9.1\end{array}$ \\
\hline$(A U L C-S U L C)$ & $a_{2}$ & $\begin{array}{l}(t) \\
(t-1) \\
\Sigma a_{2 i}\end{array}$ & $\begin{array}{l}0.141 \\
0.049 \\
0.190\end{array}$ & $\begin{array}{l}3.8 \\
1.3 \\
\ldots\end{array}$ & $\begin{array}{l}0.149 \\
0.079 \\
0.228\end{array}$ & $\begin{array}{l}3.9 \\
2.2 \\
\ldots\end{array}$ \\
\hline $\begin{array}{l}\text { Summary statistic } \\
R^{2} \\
\text { Durbin-Watson }\end{array}$ & & & $\begin{array}{l}0.6 \\
2.0\end{array}$ & & $\begin{array}{l}0.6 \\
2.0\end{array}$ & \\
\hline
\end{tabular}

Source: Text equation (1).

a. Period of fit: nonfarm, 1954:1-1971:3; nonfinancial corporate, 1958:1-1971:3.

b. $S U L C=$ standard unit labor costs; $A U L C=$ average unit labor costs. The variables are expressed as quarterly changes in logarithms.

During the period of effective price controls, between 1971:2 and 1973:1, the price of value added had risen in the private nonfarm economy by about $1 \frac{1}{2}$ percent less, and in the private nonfinancial corporate sector by about 1 percent less, than could have been predicted on the basis of the behavior of unit labor costs. By the end of 1973 that shortfall had been wiped out in both sectors. Over the two-year period from the end of effective price controls to early 1975 , prices for nonfarm products rose 20.7 percent compared with a rise of only 12.6 percent predicted by the equation on unit labor costs. In the nonfinancial corporate sector the actual increase was 17.2 percent compared with the predicted 11.5 percent rise.

\section{Reasons for Recent Movements}

Nothing in the analysis itself suggests the reasons for the recent behavior of prices relative to unit labor costs. During the period of effective price 
Table 3. Comparison of Actual Ratio of Prices to Standard Unit Labor Costs with Estimates from Equation (1), Private Nonfarm and Nonfinancial Corporate Sectors, Quarterly, 1971-75

\begin{tabular}{|c|c|c|c|c|}
\hline \multirow[b]{3}{*}{ Period } & \multicolumn{4}{|c|}{ Sector } \\
\hline & \multicolumn{2}{|c|}{ Private nonfarm } & \multicolumn{2}{|c|}{$\begin{array}{c}\text { Private nonfinancial } \\
\text { corporate }\end{array}$} \\
\hline & $\begin{array}{l}\text { Actual } \\
\text { indexes }\end{array}$ & $\begin{array}{l}\text { Estimated } \\
\text { indexes }\end{array}$ & $\begin{array}{l}\text { Actual } \\
\text { indexes }\end{array}$ & $\begin{array}{l}\text { Estimated } \\
\text { indexes }\end{array}$ \\
\hline & \multicolumn{4}{|c|}{ Price indexes $(1971: 2=100)$} \\
\hline 1971:2 & 100.0 & 100.0 & 100.0 & 100.0 \\
\hline 3 & 100.7 & 100.8 & 100.5 & 100.7 \\
\hline 4 & 100.8 & 101.6 & 100.6 & 101.2 \\
\hline 1972:1 & 101.9 & 102.6 & 101.6 & 102.0 \\
\hline 2 & 102.2 & 103.4 & 101.8 & 102.6 \\
\hline 3 & 102.6 & 104.1 & 102.2 & 103.1 \\
\hline 4 & 103.4 & 105.0 & 102.8 & 103.6 \\
\hline 1973:1 & 104.3 & 106.0 & 103.5 & 104.4 \\
\hline 2 & 105.7 & 107.2 & 104.7 & 105.4 \\
\hline 3 & 107.0 & 108.5 & 105.9 & 106.6 \\
\hline 4 & 108.9 & 110.0 & 107.1 & 107.8 \\
\hline 1974:1 & 111.7 & 111.6 & 109.3 & 109.3 \\
\hline 2 & 115.5 & 113.4 & 112.5 & 110.9 \\
\hline 3 & 119.0 & 115.3 & 115.6 & 112.7 \\
\hline 4 & 122.8 & 117.4 & 118.7 & 114.6 \\
\hline \multirow[t]{2}{*}{ 1975:1 } & 125.9 & 119.4 & 121.3 & 116.4 \\
\hline & \multicolumn{4}{|c|}{ Percent changes } \\
\hline $1971: 2-1973: 1$ & 4.3 & 6.0 & 3.5 & 4.4 \\
\hline 1973:1-1974:1 & 7.1 & 5.3 & 5.6 & 4.7 \\
\hline 1973:1-1975:1 & 20.7 & 12.6 & 17.2 & 11.5 \\
\hline
\end{tabular}

Source: Actual, table 1; estimated, text equation (1).

controls the behavior of prices relative to unit labor costs supports Robert Gordon's 1973 findings that Phase II price and wage controls did squeeze margins. ${ }^{4}$ It seems eminently reasonable to attribute the initial rise in prices relative to unit labor costs during 1973 to the gradual dismantling of controls. And some of the further expansion in the margin during 1974 might be ascribed to fears of renewed imposition of price and wage controls. But the magnitude of the expansion, and its continuation in the face of overwhelming congressional hostility to a reimposition of controls and of the

4. Robert J. Gordon, "The Response of Wages and Prices to the First Two Years of Controls," $B P E A, 3: 1973$, pp. 765-78. 
sharpest sag in aggregate demand since the 1930s, suggests that much more was involved than the simple fear of future controls. Several hypotheses can be offered:

\section{INCREASES IN IMPORT PRICES}

As Gordon points out, the structurally expected effect of increases in import prices in eliciting sympathetic rises in prices of competing domestic products cannot be coaxed from the time-series data prior to 1973 because the variance in the relative price of imports was so small during the period. It is hard to believe, however, that the sharp rise in import prices (apart from food and fuel) beginning in 1973 did not elicit significant price gains among competing domestic products. So long as the relative price of competitive imports does not fall (through differential price behavior abroad or dollar appreciation), and so long as unit labor costs do not rise to fill the gap, a disequilibrium remains, in the sense that the full-employment profit rate will remain above "normal." (In a deep recession like the current one, this fact may be hidden by the cyclical depression of actual productivity and the corresponding rise in actual unit labor costs-hence the kinship of the full-employment profit rate and the full-employment budget surplus, noted above.)

\section{THE RISING COST OF CAPITAL GOODS}

The price equations set out earlier incorporate, during the period of fit, a very slight downward trend in the ratio of price to standard unit labor costs. In the private nonfarm sector, standard unit labor costs represented 56.5 percent of price in 1967 . The price equation implies that apart from cyclical variations, prices will rise by 0.5 percent per year plus 0.75 percent for each 1 percent rise in standard unit labor costs. On a steady-state basis this means that whenever standard unit labor costs rise by more than 2 percent per year, prices will increase by less than that rise. The "break-even" point for the nonfinancial corporate sector is a 1.3 percent annual rise in standard unit labor costs. Obviously, this is not a well-specified structural relationship. In a sustained period of very much larger rises in standard unit labor costs, or when prices of capital goods rise significantly faster than standard unit labor costs, the relationships of price to unit labor cost implied in the equations clearly will not hold up. 
In the purely competitive world, a sustained and rapid rise in prices of capital goods would tend to reduce the marginal efficiency of investment to the point where capacity expansion was slowed relative to the growth of demand (under conditions of full employment). Prices would then rise relative to standard unit labor costs by enough to restore rates of return on investment. In a world of administrative pricing rules, in which prices are increased as standard direct costs rise but some attention is paid to a target rate of return, an acceleration of inflation would likely initiate the following sequence:

First, the old pricing rules, relating prices to standard direct costs, would be followed.

Second, this practice would depress the margin of prices relative to standard unit labor costs, and yield a decreasing rate of return to new investment, since capital-goods prices would begin to rise faster than the rate of increase in the nonlabor returns per unit of output.

Third, rather than waiting for the classical long-run adjustment to take place through the slowdown of capacity expansion, price policy in the dominant administered-price sector would be adjusted to correct margins for the inadequacy of historical pricing rules.

Fourth, this development would reverse the downdrift of the ratio of price to standard unit labor costs and restore it to earlier levels.

To get some impression of the potential magnitude of price changes related to capital recovery, I have constructed a price series for the private nonfinancial corporate sector based on a set of pricing rules designed to yield, at standard output volume, an unchanged rate of return to capital, priced at reproduction costs. This series was concocted, using 1969 as a base year, by setting prices so as (1) to recover standard unit labor costs; (2) to recover that fraction of the deviation of actual from standard unit labor costs implied in the price equation discussed earlier; (3) to recover indirect taxes per unit of output (with a small adjustment to allow recovery of property taxes at standard volumes of output); (4) to recover, at standard volumes of output, the 1969 capital costs per unit (net interest, depreciation, and profits) extrapolated by the price deflator for nonresidential fixed investment.

Assuming a constant ratio of capital stock to capacity output and a constant real interest rate, the resultant price level would yield, at standard output volume, the 1969 rate of return on incremental investment, priced at 
Table 4. Actual, Fitted, and Simulated Prices, Costs, and Gross Margins per Unit of Output, Private Nonfinancial Corporate Sector, Selected Periods, 1969-75

\begin{tabular}{|c|c|c|c|c|c|c|}
\hline \multirow[b]{2}{*}{ Period and item } & \multicolumn{4}{|c|}{ Price component } & \multirow{2}{*}{$\begin{array}{c}\text { Price } \\
\text { change } \\
\text { from } \\
\text { previous } \\
\text { period } \\
\text { (percent) }\end{array}$} & \multirow{2}{*}{$\begin{array}{c}\text { Cyclical } \\
\text { absorption } \\
\text { incorporated } \\
\text { in gross } \\
\text { margin }\end{array}$} \\
\hline & $\begin{array}{l}\text { labor } \\
\text { costs }\end{array}$ & $\begin{array}{c}\text { Indirect } \\
\text { taxes }\end{array}$ & $\begin{array}{c}\text { Gross } \\
\text { margins }\end{array}$ & Total & & \\
\hline 1969 (base) & 65.7 & 9.4 & 24.9 & 100.0 & $\cdots$ & -0.2 \\
\hline \multicolumn{7}{|l|}{ 1971:2 } \\
\hline \multicolumn{6}{|l|}{ Target-rate-of-return } & \multirow{3}{*}{0.4} \\
\hline Actual & 71.3 & 10.8 & 26.0 & 108.1 & 8.1 & \\
\hline Fitted & 71.3 & 10.8 & 24.7 & 106.8 & 6.8 & \\
\hline \multicolumn{7}{|l|}{$1973: 1$} \\
\hline \multicolumn{6}{|l|}{ Target-rate-of-return } & \multirow{3}{*}{-1.2} \\
\hline Actual & 73.8 & 10.5 & 27.7 & 112.0 & 3.6 & \\
\hline Fitted & 73.8 & 10.5 & 27.2 & 111.5 & 4.4 & \\
\hline \multicolumn{7}{|l|}{$1975: 1$} \\
\hline \multicolumn{7}{|l|}{ Target-rate-of-return } \\
\hline Actual & 89.8 & 12.7 & 28.6 & $131.1^{\mathrm{a}}$ & 17.1 & \multirow[t]{2}{*}{3.5} \\
\hline Fitted & 89.8 & 12.7 & 21.9 & 124.4 & 11.6 & \\
\hline
\end{tabular}

Sources: Actual, table 1; fitted, table 3; simulation, see text; all data converted to indexes, $1969=100$. a. The actual total price for 1975:1 was adjusted by 1.8 percent to exclude increases in energy prices.

reproduction costs. ${ }^{5}$ The realized capital recovery per unit of output would vary from the target by the absorption of cyclical variations in unit labor costs.

The results of this simulation-in terms of prices and costs-are shown in table 4 . They are also compared both with actual prices and margins and with those implied in the pre-1971 fitted relationship of prices to unit labor costs.

In the roughly two years between 1969 and the quarter just preceding the

5. The price-cost relationships would generate (1) a return on new investment equal to the 1969 return on invested capital; and (2) a series of "capital gains" sufficient to recover the difference between real and nominal rates if the excess of the nominal interest rate over the real rate correctly anticipated the rate of inflation. 
imposition of price controls, actual prices rose more than the calculated value from the labor-cost equation and somewhat less than the target-rateof-return simulation. After two years of controls, prices had risen by slightly less than either the labor-cost equation or the target-rate simulation suggested. In the succeeding two years, however, the rises in the actual and simulated indexes were virtually the same and much larger than predicted by the labor-cost equation.

\section{A REDUCTION IN EXPECTED OUTPUT LEVELS}

To the extent that pricing decisions are made with a target rate of return in mind, changes in expectations about the long-run average rate of capacity utilization could affect the markup of prices over standard unit labor costs. If both average expected output and peak expected output fall (and by the same amount), there should be no effect on margins, since the fall in average expected output would be matched by a fall in capacity requirements. But if average expected output falls by more than peak expected output, gross capital returns per unit of output will have to rise to yield the target rate of return on investment.

Figure 2 traces a twenty-quarter moving average of the ratio of actual to potential GNP. While this is hardly the most sophisticated indicator, its movements should provide some measure of long-run changes in expected utilization levels. To the extent that rules of thumb in pricing policy are influenced by the target rate of return, an increase in expected utilization rates should lower, and a decrease should raise, the ratio of price to standard unit labor costs.

\section{A Test of the Hypotheses}

To the extent that the hypotheses discussed above are valid, the ratio of price to standard unit labor costs should be influenced by the following factors: The long-run factors are the relative price of capital goods (positive), and the long-run expected rate of capacity utilization (negative). The short-run factors are the deviation of actual from standard unit labor costs (positive), and the ratio of current to long-run expected capacity utilization (positive, reflecting the state of excess demand). 


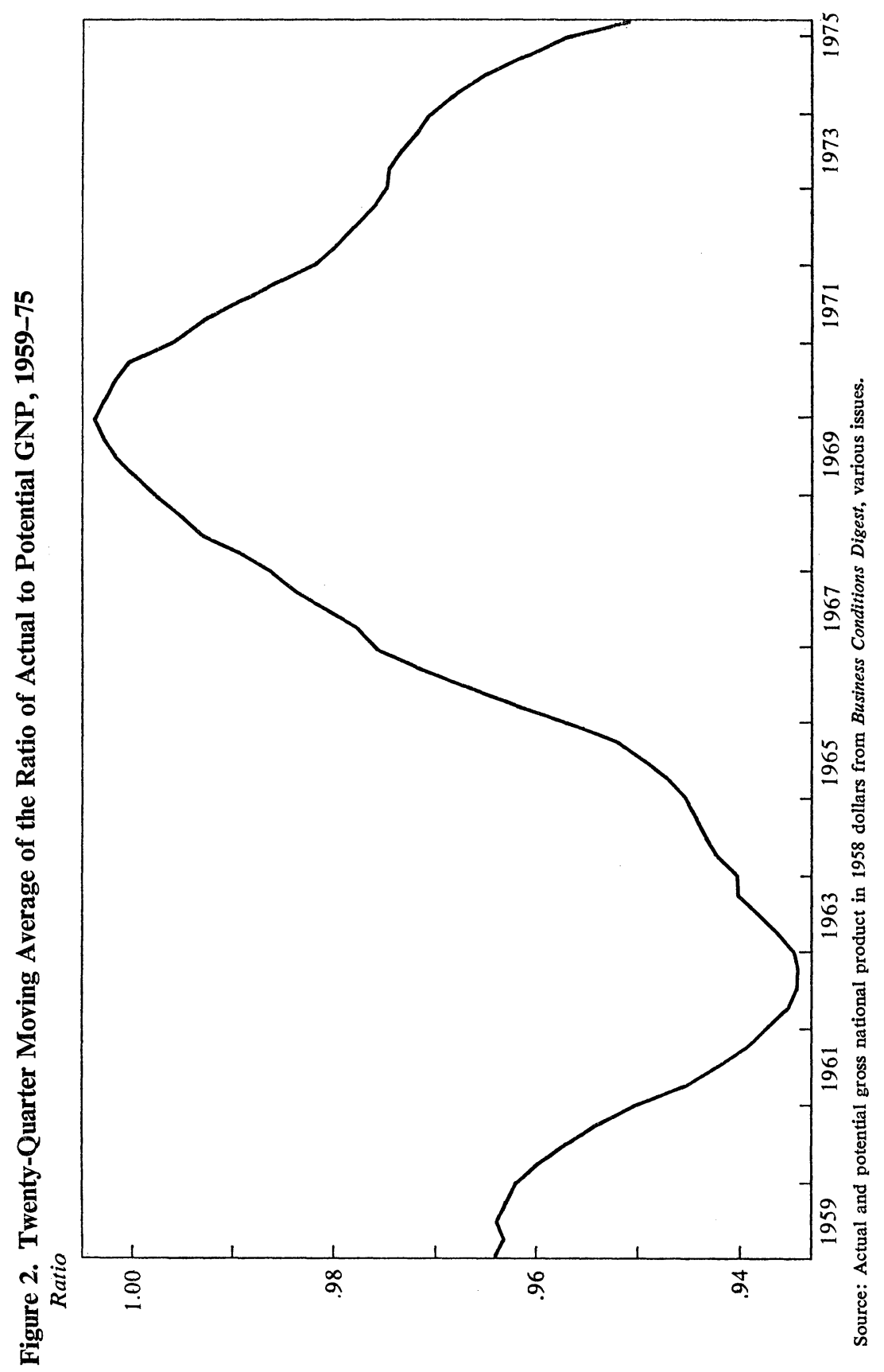


The following equation was fitted to the quarterly ratio of prices to standard unit labor costs for the private nonfarm sector:

$$
\begin{gathered}
\frac{P_{t}}{S U L C_{t}}=a_{0}+a_{1}\left(\frac{A U L C}{S U L C}\right)_{t}+a_{2}\left[\frac{y}{y p}-\left(\frac{y}{y p}\right)^{*}\right]_{t} \\
+a_{3}\left(\frac{y}{y p}\right)_{t}^{*}+a_{4}\left(\frac{P I}{P}\right)_{t}^{*}+a_{5} t+a_{6} D+u_{t},
\end{gathered}
$$

where

$$
\begin{aligned}
P & =\text { price deflator }(1967=1.00) \\
A U L C & =\text { actual unit labor costs }(1967=1.00) \\
S U L C & =\text { standard unit labor costs } \\
t & =\text { time }(1958: 4=1) \\
y & =\text { actual GNP } \\
y p= & \text { potential GNP } \\
(y / y p)^{*}= & \text { five-year moving average of } y / y p \\
(P I / P)^{*} & =\text { one-year moving average of the relative price of business fixed } \\
& \text { investment } \\
D= & \text { price-control dummy }(1971: 3-1974: 1=1.0 ; 0 \text { otherwise }) \\
u= & \text { error term. }
\end{aligned}
$$

Two forms of the equation were tried, one using the lagged value of the dependent variable, the other using independent lag structures and a rho correction. In addition, both sets of equations were fitted first to the period 1958:4 to $1971: 2$ and then to the longer period 1958:4 to $1974: 1$. The basic results are shown in table 5 . The coefficient on the relative price of capital goods was in no case significant, and was of the wrong sign. All of the equations in table 5 were refitted without it.

Various lag structures were tried for alternative B, the equations without the lagged dependent variable. In all cases the coefficients on the lagged values of deviations of actual from standard unit labor costs and on the lagged values of the demand term were highly insignificant, and clearly "interfered" with each other. The measure of expected long-term capacity utilization $(y / y p)^{*}$ is itself a twenty-quarter moving average and needs no lag. Only the price-control dummy seemed to require a lag structure. Since the margin-squeezing effect of price controls operated through delays and refusals to allow a full cost passthrough, a constant degree of control would result in a gradual squeezing of margins, at least for a while, as costs rose. Relaxing the severity of controls could imply a maintenance of the squeeze on margins at a constant level (that is, the generally acknowledged 
easing of controls that accompanied the introduction of Phase III in early 1973 need not have implied a widening of margins, only a cessation of the previously tightening squeeze). Finally, abandonment of controls should have led to a gradual restoration of margins. A four-quarter, first-order Almon lag was chosen, and, as expected, the negative coefficients on the constant dummy term increased in value over the four quarters.

The lower bank of data in table 5 compares the steady-state coefficients from alternative A with the coefficient values and the sum of the dummy coefficients from alternative B. Except for the version of alternative A fitted through 1974:1, the effects of deviations in actual unit labor costs and of long-term changes in capacity utilization are virtually the same. About 60 percent of any deviation in actual from standard unit labor costs is passed through into prices. (Unit labor costs are approximately 57 percent of prices; $0.35 / 0.57=0.61$.) This effect of deviations in actual from standard unit labor costs is somewhat higher than those observed by others, which tend to take on a value of 0.2 rather than the 0.35 in the current equations. ${ }^{6}$ But, as shown below, the current estimate holds up well when projected past the fitting period.

In the equation with the lagged dependent variable fitted through 1974:1, the price-control dummy probably forces the coefficient on the lagged dependent variable to an artificially high level, given the hypothesis suggested above that the initial effect of price controls was to squeeze margins gradually. ${ }^{7}$ In turn this blows up the steady-state coefficient on the ratio of $A U L C$ to $S U L C$ to an excessively high number. (Since the $(y / y p)^{*}$ term is a smooth long-lagged variable, its raw coefficient value adjusts to the rise in the coefficient on the lagged dependent variable, so its steady-state value is not so much distorted.)

The coefficient on long-term capacity utilization implies that a 1 percent reduction in long-term expectations about the utilization rate results in a 0.35 to 0.40 percent price increase. This result is slightly above what would be predicted by a target-rate-of-return hypothesis. Capital-recovery costs, in normal times, are 27 percent of price in the corporate sector; a 1 percent "permanent" drop in capacity utilization would therefore require a 0.27 percent change in price to maintain the rate of return on invested capital unchanged, compared with the 0.35 to 0.40 percent change implied by the equations.

6. See Gordon, "Response of Wages and Prices."

7. If the dummy is constant, its gradual impact on margins can be reflected only by an increase in the value of the coefficient on $P / S U L C_{-1}$. 
Table 5. Results of Alternative Estimates of Equation (2)

\begin{tabular}{|c|c|c|c|c|c|c|c|}
\hline \multirow{2}{*}{$\begin{array}{l}\text { Variable }^{\mathrm{a}} \\
\text { and } \\
\text { summary } \\
\text { statistic }\end{array}$} & \multicolumn{3}{|c|}{$\begin{array}{c}\text { Alternative } A^{\mathrm{b}} \\
\text { Equation with lagged } \\
\text { dependent variable }\end{array}$} & \multicolumn{4}{|c|}{$\begin{array}{c}\text { Alternative } B^{\mathbf{b}} \\
\text { Equation without lagged } \\
\text { dependent variable }\end{array}$} \\
\hline & \multicolumn{2}{|c|}{$\begin{array}{c}\text { Fitted } \\
\text { through } \\
1974: 1\end{array}$} & $\begin{array}{l}\text { Fitted } \\
\text { through } \\
\text { 1971:2 }\end{array}$ & \multicolumn{2}{|c|}{$\begin{array}{l}\text { Fitted } \\
\text { through } \\
1974: 1\end{array}$} & \multicolumn{2}{|l|}{$\begin{array}{l}\text { Fitted } \\
\text { through } \\
1971: 2\end{array}$} \\
\hline & \multicolumn{7}{|c|}{ Coefficient and $t$-statistic } \\
\hline Variable & & & & & & & \\
\hline Constant & 0.298 & 1.6 & $0.712 \quad 3.3$ & 1.044 & 7.2 & 1.050 & 8.0 \\
\hline$A U L C / S U L C$ & 0.224 & 3.1 & $0.242 \quad 3.3$ & 0.345 & 3.8 & 0.347 & 3.8 \\
\hline$\left[y / y p-(y / y p)^{*}\right]$ & 0.046 & 1.0 & $0.061 \quad 1.4$ & 0.033 & 0.5 & 0.073 & 1.3 \\
\hline$(y / y p)^{*}$ & -0.127 & 2.0 & $-0.264 \quad 3.6$ & -0.390 & 4.3 & -0.399 & 5.6 \\
\hline$t$ & -0.0003 & 2.9 & -0.00044 .3 & -0.0006 & 5.2 & -0.0006 & 6.0 \\
\hline$\Sigma D_{t}$ & $\ldots$ & & $\ldots$ & -0.023 & 4.9 & $\ldots$ & \\
\hline$(t)$ & -0.007 & 2.2 & $\ldots$ & -0.004 & 1.3 & $\ldots$ & \\
\hline$(t-1)$ & . & & $\ldots$ & -0.005 & 3.3 & $\ldots$ & \\
\hline$(t-2)$ & $\ldots$ & & $\ldots$ & -0.006 & 4.3 & $\ldots$ & \\
\hline$(t-3)$ & $\ldots$ & & $\ldots$ & -0.008 & 2.6 & $\ldots$ & \\
\hline$(P / S U L C)_{-1}$ & 0.606 & 6.5 & $0.309 \quad 2.5$ & $\ldots$ & & $\ldots$ & \\
\hline \multirow[t]{2}{*}{ Rho } & $\ldots$ & & $\ldots$ & 0.642 & & 0.507 & \\
\hline & \multicolumn{7}{|c|}{ Steady-state value of coefficient } \\
\hline$A U L C / S U L C$ & 0.569 & & 0.350 & 0.345 & & 0.347 & \\
\hline$\left[y / y p-(y / y p)^{*}\right]$ & 0.117 & & 0.088 & 0.033 & & 0.073 & \\
\hline$(y / y p)^{*}$ & -0.322 & & -0.382 & -0.390 & & -0.399 & \\
\hline$t$ & -0.0008 & & -0.0006 & -0.0006 & & -0.0006 & \\
\hline$D$ & -0.0178 & & $\ldots$ & -0.023 & & $\ldots$ & \\
\hline Summary statistic & \multicolumn{7}{|c|}{ Value of summary measure } \\
\hline $\bar{R}^{2}$ & 0.975 & & 0.964 & $0.891^{\circ}$ & & $0.942^{\circ}$ & \\
\hline Durbin-Watson & 2.036 & & 1.742 & 1.950 & & 1.877 & \\
\hline Standard error & 0.004 & & 0.004 & 0.004 & & 0.003 & \\
\hline
\end{tabular}

a. $A U L C=$ actual unit labor costs; $S U L C=$ standard unit labor costs; $y / y p=$ ratio of actual to potential GNP, and * signifies five-year moving average; $t=$ time; $D=$ price-control dummy; $P=$ price deflator.

b. The fitting period for all four versions of the equation begins in 1958:4.

c. Dynamic $R^{2}$.

The demand term is small and in no case significant, although it does carry the "right" sign. Quite possibly, however, a gradual demand effect is being roughly offset by a growing effect on price of the $A U L C / S U L C$ term. Since movements in $A U L C / S U L C$ are dominated by cyclical productivity changes, which in turn are negatively correlated with demand, the two effects tend to cancel out. ${ }^{8}$

8. But see the discussion of productivity in the appendix. 
Table 6. Actual and Predicted Values of the Ratio of Prices to Standard Unit Labor Costs, Private Nonfarm Sector, Quarterly, 1974:2 to $1975: 2$

\begin{tabular}{rccc}
$\begin{array}{c}\text { Year and } \\
\text { quarter }\end{array}$ & $\begin{array}{c}\text { Actual } \\
(1)\end{array}$ & $\begin{array}{c}\text { Predicted } \\
(2)\end{array}$ & $\begin{array}{c}\text { Error } \\
(1)-(2)\end{array}$ \\
\hline $1974: 2$ & 96.1 & 96.4 & -0.3 \\
3 & 97.3 & 97.0 & 0.3 \\
4 & 98.6 & 98.0 & 0.6 \\
$1975: 1$ & 99.3 & 99.0 & 0.3 \\
2 & 99.0 & 99.3 & -0.3 \\
\hline
\end{tabular}

Sources: Actual values, table 1; predicted values, alternative B of text equation (2) fitted through 1974:1.

Table 6 compares the actual values of $P / S U L C$ during 1974:2 to $1975: 2$ with values predicted from the alternative $B$ equation, fitted through 1974:1. The equation predicts the upsurge in margins very well. And although the removal of price controls contributed about 40 percent of the rise (which any equation with a lagged dummy term might have approximated), changes in several of the other variables are quite important.

Table 7 shows the factors that contributed to the rise in $P / S U L C$ over the past two years-from its low point in 1973:2 to 1975:2.9

The findings might now be summarized as follows:

1. Long-term changes in expected capacity utilization affect prices by slightly more than would be expected if pricing based on a target rate of return were common.

2. About 60 percent of cost changes stemming from cyclical changes in productivity are passed on in prices.

3. Changes in the degree of excess capacity have little effect on margins (whatever they may do to wages). The close relationship between cyclical changes in actual unit labor costs and in excess capacity, however, may obscure two distinct but offsetting effects: lagged cyclical changes in actual unit labor costs tending to raise prices and lagged demand changes tending to lower them.

4. Price controls appear to have gradually reduced prices by 2 to $2 \frac{1}{2}$ percent.

About 40 percent of the sharp rise in prices relative to standard unit labor costs over the past two years appears to have been due to the removal of

9. Actually, there is a sudden one-quarter dip in $P / S U L C$ in 1973:1 not picked up in the equation (see figure 1). This dip was ignored in choosing the low point. 


\section{Table 7. Factors Contributing to the Rise in the Ratio of Prices to Standard Unit Labor Costs, Private Nonfarm Sector, 1973:2 to $1975: 2$}

Percentage points

\begin{tabular}{lr}
\hline \multicolumn{1}{c}{ Component of rise } & Rise \\
\hline Total rise in P/SULC & 5.21 \\
Deviation in actual unit labor costs & 2.48 \\
Removal of price controls & 2.30 \\
Reduction in long-term capacity utilization & 1.08 \\
Time trend & -0.48 \\
Falling demand & -0.36 \\
Residual and rho correction & 0.19 \\
\hline
\end{tabular}

Source: Estimated from alternative B of text equation (2), fitted through 1974:1.

controls. Almost all of the remainder, paradoxically, stems from the net impact of sharply declining levels of economic activity, through the effect of cyclical declines in productivity and a fall in expectations about longterm capacity utilization. However successful it may be in moderating wage inflation, depression of aggregate demand-especially if continued for long periods-appears to be counterproductive in its effects on price-wage margins. The large margin-raising effects of reduced aggregate demand are not apparent to the naked eye in prior recessions principally because those recessions were neither as sharp nor as long as the current one.

Could other potential culprits be responsible for the recent rise in price margins - the competitive effects of rising import prices, the fear of the reimposition of controls, and escalating expectations of long-term inflation? Have one or more of the independent variables used in equation (2) recently taken on values out of line with past experience, thereby serving as surrogates for a dummy variable that picks up one of the factors cited above? The fact that the version of the equation fitted through 1971:2 has virtually the same coefficients as the version fitted through 1974:1 means that the structure captured in that equation could fully predict the recent rise in margins (after adjustment for the removal of price controls). Hence the explanation relying on a surrogate dummy variable will not hold. To the extent that some factor other than those included in equation (2) drove up price margins, some offsetting change in the earlier structure must have occurred simultaneously. On balance it seems more probable that the extent and depth of the recent depression in aggregate demand, operating on an unchanged structure, have been responsible for the margin increase. 


\section{Implications for the Future}

What does the foregoing imply for the movement of the ratio of price to standard unit labor costs if a rapid recovery takes place during the next eighteen months? Using the alternative B equation fitted through 1974:1, I have made a projection based on several simple assumptions: (1) real GNP rises at a steady 8 percent annual rate starting in the third quarter of 1975; (2) compensation per manhour in the private nonfarm sector also rises at an 8 percent annual rate; and (3) productivity behaves in accordance with the equation discussed earlier (in the second quarter of 1975 the residual from that equation was virtually zero). Given these assumptions, the ratio of prices to standard unit labor costs remains virtually constant, in the neighborhood of 99.0 through the end of 1976. The favorable effect of the decline in actual relative to standard unit labor costs is fully offset by the continued fall in the long-term moving average of the capacity-utilization variable and the rise in the current capacity-utilization term.

Several additional points should be noted. First, the trend rate of increase in productivity incorporated in the $S U L C$ variable is only 2 percent per year, somewhat less than usually assumed. ${ }^{10}$ Hence, an 8 percent rise in compensation per manhour translates into a 6 percent rise in standard unit labor costs. Second, the cyclical productivity adjustment tends systematically to understate the fall in productivity during the early downturn and to overstate the rise during the early upturn. The drop in $A U L C / S U L C$ in the projection may, therefore, be understated and $P / S U L C$ slightly overestimated during the next four quarters.

The central point of the projections is that the nonfarm price deflator (excluding domestic energy rents) is likely to be determined mainly by wage changes during the early phases of the recovery. While this is hardly a

10. The growth rate of productivity between $1955: 4$ and $1965: 4$, in both of which $y / y p$ was the same, was 2.61 percent; the equation shows a 2.55 percent trend for this period. Productivity growth between 1965:2 and 1973:1 (also periods with the same $y / y p$ ) was 2.15 percent; the equation has a 1.95 percent trend for this period. The difference between the peak-to-peak growth in productivity is almost exactly the same as the difference between the two trends in the equation. An equation fitted with only one trend yields a 2.2 percent trend for the entire period, and a slightly larger cyclical adjustment term ( 0.47 instead of 0.42$)$. An equation using two time trends, and, as a cyclical variable, lagged changes in output relative to trend, also yields a 2.0 percent productivity trend for the recent period (see the appendix). 
startling conclusion, it implies a sharp departure from the price behavior of the past two years.

One of the major features of the 1973-74 downturn was the erosion in real wages, which led to a sharp fall in real disposable personal income. The role in this phenomenon of rising prices for oil and other imports has long been recognized. But the rise in the ratio of prices to wages has been much larger than can be accounted for by these developments. To the extent that the steady-state coefficients on $A U L C / S U L C$ and on long-term expectations about utilization derived earlier approximate structural reality, sharp and prolonged recessions tend to raise prices significantly relative to standard unit labor costs. Whatever an extended depression of aggregate demand does to wage rates, it is not an effective way of squeezing pricewage margins.

\section{APPENDIX}

\section{Derivation of Trend Productivity Increase to Calculate Standard Unit Labor Costs}

FOR вотн sectors, private nonfarm and private nonfinancial corporate, output per employee hour $(Q / H)$ was fitted to a time trend and a cyclical adjustment term (the ratio of actual to potential GNP, $y / y p$ ). Productivity data are indexed to $1967=100$.

The regression for private nonfarm productivity is

$$
\begin{aligned}
& \ln \left(\frac{Q}{H}\right)_{t}=\underset{(1212)}{4.281} D_{1}+4.339 D_{2}+0.00639 D_{1}(t) \\
& +\underset{(24)}{0.00487} D_{2}(t)+\underset{(10)}{0.419} \ln \left(\frac{y}{y p}\right)_{t}, \\
& \bar{R}^{2}=0.994 ; \text { Durbin-Watson statistic }=0.339 \text {. }
\end{aligned}
$$

where

$$
\begin{aligned}
& D_{1}=1,1954: 1-1965: 4 ; 0 \text { otherwise } \\
& D_{2}=1,1966: 1-1975: 2 ; 0 \text { otherwise. }
\end{aligned}
$$


The regression for productivity in the private nonfinancial corporate sector is

$$
\begin{aligned}
& \text { (A-2) } \quad \ln \left(\frac{Q}{H}\right)_{t}=\underset{(1222)}{4.300+(100)} 0.00725(t)+\underset{(12)}{0.503} \ln \left(\frac{y}{y p}\right)_{t} . \\
& \vec{R}^{2}=0.994 ; \text { Durbin-Watson statistic }=0.367 \text {. }
\end{aligned}
$$

The numbers in parentheses are $t$-statistics.

Standard unit labor costs are estimated by setting $y / y p$ at a constant 0.97 , calculating a standard productivity, and dividing that into the actual compensation per hour. Since two time trends (with different intercepts) were used in the private nonfarm sector, a discontinuity in the measurement of standard productivity was avoided by locating the intersection of the two productivity trends (1963:2) and switching from one trend to the other at that point.

An alternative productivity equation was tried for the private nonfarm sector, in which quarterly changes in productivity were fitted against two time trends and a lagged series of quarterly changes in actual output relative to potential:

$$
\begin{gathered}
\Delta \ln \left(\frac{Q}{H}\right)_{t}=a_{0} D_{1}+a_{1} D_{2}+a_{2} \Delta \ln \left(\frac{y}{y p}\right)_{t} \\
+\sum_{i=t-1}^{t-5} a_{3 i} \Delta \ln \left(\frac{y}{y p}\right)_{i}+u_{t},
\end{gathered}
$$

where

$$
\begin{aligned}
& D_{1}=1,1956-65 ; 0 \text { otherwise } \\
& D_{2}=1,1966-75 ; 0 \text { otherwise. }
\end{aligned}
$$

The results of (A-3) are given in table A-1; the coefficients $a_{0}$ and $a_{1}$ are expressed as annual rates of change, in percent, and the weighting structure for the sum of the $a_{3}$ s is from a second-order Almon lag.

For purposes of this paper the important point is the confirmation of the 2 percent value for the recent time trend. The results are also interesting for what they say about cyclical productivity change. For each 1 percent drop in output below trend, productivity at first drops 0.6 percent. If output then resumes a movement parallel to trend, three-quarters of the productivity shortfall will be made up after six quarters, in what is virtually a declining geometric pattern. (Since a second-order Almon lag was imposed, a geometric decline is not forced upon the weighting structure.) A freely fit- 
ted lag structure gave virtually the same coefficients for the first quarter and the sum of the remaining five quarters $(0.62 ;-0.46)$. An eight-quarter Almon lag, for quarters after the current one, also gave similar results $(0.59 ;-0.46)$, but the negative coefficients deteriorated rapidly in significance after the fourth quarter, and the sum of the negative weights was no greater than that in the five-quarter structure.

Table A-1. Results of Estimates of Equation (A-3)

\begin{tabular}{lcc}
\hline $\begin{array}{c}\text { Coefficient and } \\
\text { summary statistic }\end{array}$ & Value & t-statistic \\
\hline Coefficient & & \\
$a_{0}$ & 2.59 & 8.0 \\
$a_{1}$ & 2.02 & 5.7 \\
$a_{2}$ & 0.613 & 10.5 \\
$\Sigma a_{3 i}$ & -0.452 & 4.6 \\
$\left(a_{3},-1\right)$ & -0.165 & 2.7 \\
$\left(a_{3},-2\right)$ & -0.117 & 4.2 \\
$\left(a_{3},-3\right)$ & -0.080 & 2.1 \\
$\left(a_{3},-4\right)$ & -0.053 & 1.9 \\
$\left(a_{3},-5\right)$ & -0.037 & 0.7 \\
Summary statistic & & \\
$\bar{R}^{2}$ & 0.622 & $\ldots$ \\
Durbin-Watson & 1.875 & $\ldots$ \\
\hline
\end{tabular}

\section{Discussion}

Most of the discussion focused on the interpretation of the recent behavior of the ratio of price to standard unit labor cost $(P / S U L C)$. R. A. Gordon introduced the possibility that the observed widening of the pricecost margin since early 1973 could reflect a shift in thinking on the part of firms from historical to anticipated standard unit labor costs. In an inflationary period, the ratio of price to historical cost would rise even though the ratio of price to anticipated cost was constant. William Nordhaus suspected that the recent rise in $P / S U L C$ might be overstated by Schultze 
as the result of an insufficient adjustment for increases in energy prices. Schultze's adjustment seemed distinctly smaller than similar estimates by John Shoven and Nordhaus, which had indicated a marked-up rise of roughly $\$ 2$ in final energy-product prices for each $\$ 1$ increase in the cost of crude oil. Any understatement of the energy effect would overstate the rise of $P / S U L C$ to be explained by other causes. Nordhaus also noted that the turnaround in the margin coincided approximately with the 1973 Mideast war.

More generally, Nordhaus was uncomfortable with the implicit assumption of the paper that pricing behavior is based solely on labor costs. What appears as an enlarged markup of value-added prices over labor costs since 1973 in reality might be a constant markup on both labor and materials costs, following a major relative increase in materials costs. Robert Hall elaborated on that criticism. He noted that the price measure of the paper, the private nonfarm deflator, was a value-added price index which necessarily abstracted from two major nonwage sources of the recent inflation, farm and import prices. He would have preferred a measure of the price of final goods rather than of value added.

Schultze replied that his analysis was based implicitly on a model with a long-run target rate of return, for which the adjusted deflator was the appropriate price measure. A more inclusive price measure would raise aggregation problems in interpreting pricing behavior as aiming at a target rate of return based on a markup over all costs. He thought it unlikely that pricing rules at the initial stage of processing would mark up very volatile prices of raw materials; at more advanced stages of processing, the rawmaterials component of costs might be incorporated in a pricing rule, but would be less volatile. A value-added deflator finesses some of these problems. George Perry viewed the aggregation problem as less important for the broad private nonfarm sector, which acquires most of its purchased inputs from industries within the sector, than it would be for a smaller sector or a particular industry.

William Fellner suggested that, if, in fact, firms were passing on their tax burden from FIFO inventory accounting, that would show up as a widening of margins that the equation might wrongly attribute to the gap between standard and actual productivity. Robert Solow called attention to Schultze's two-part explanation of the drop in the P/SULC margin between 1960 and 1971, which invoked a negative-time trend and an increase in the expected long-run rate of capacity utilization. Solow sus- 
pected that the large negative-trend effect might in fact reflect the influence of some omitted structural variable.

Christopher Sims expressed doubts that Schultze's equation could be confidently interpreted as reflecting pricing behavior. It could instead describe wage behavior, since the estimated equation approximates a relationship involving the reciprocals of the real wage, of output per worker, and of output.It could be saying something about the production function, since transposing output per worker to the left-hand side of the equation and the real wage to the right yields an equation that could be used to estimate the elasticity of substitution. Finally, it could be saying something about the stability of relative shares-that the ratio of total wages to nominal income tends to be stable in the long run. All in all, the a priori information seemed inadequate to Sims to identify the equation as an explanation of markup behavior rather than as a description of the behavior of other elements that enter into the determination of the markup. 